\title{
Take a Ride on Credibility: The Role of Brand Personality in Users' Loyalty to Virtual Brands in the Sharing Economy
}

\author{
Lucas Moreno ${ }^{1}$, Gisela Demo, Thelma Valéria Rocha ${ }^{\ddagger}$, Fernanda Scussel ${ }^{*}$ \\ Universidade de Brasília - UnB, Brasília, DF, (Brasil) \\ Escola Superior de Propaganda e Marketing - ESPM, São Paulo, SP (Brasil) ${ }^{£}$ \\ Universidade Federal de Santa Catarina - UFSC, Florianopolis, SC (Brasil) ${ }^{*}$
}

\begin{tabular}{l}
\hline ARTICLE DETAILS \\
\hline Article history: \\
Received: 01 Julyl 2020 \\
Accepted: 15 april 2021 \\
Available online May: 01 th 2021 \\
Double Blind Review System \\
Scientific Editor \\
Ilan Avrichir \\
\hline Keywords \\
Customer Relationship Management \\
Loyalty \\
Brand Personality \\
Virtual Brands; \\
Sharing Economy.
\end{tabular}

\begin{abstract}
Objective: Although the sharing economy is a global phenomenon, being a path to create international brands with a worldwide customer reach, the relationship between virtual brands and users' in this new sector remains underexplored, leading us to investigate the relation between brand personality and users' loyalty to virtual brands.
\end{abstract}

Method: Survey with 580 users of ride apps, using structural equation modeling to test the prediction of brand personality on user's loyalty.

Results: The present research depicts the intangible aspects of the relationship between users and brands in the digital environment, revealing the personality traits of virtual brands and the impact on customer loyalty in the context of the sharing economy. Credibility and audacity are the most prominent characteristics of virtual brands, being credibility, reflecting the users' trust in the brand, the main driver of loyalty.

Contributions: These findings contribute to the relationship marketing body of knowledge; in a sense, it provides information about how customers relate to their favorite virtual brands and indicates an antecedent of relationship marketing. Customer brand relationship studies also benefit from our results since we suggest important factors that enable positive associations about a brand in consumers' minds.

Relevance/Originality: This study represents a seminal step in investigating the relational aspects of the interaction between users and virtual brands in the sharing economy, which has brought the need to rethink brand management and brand positioning in the context of virtual brands.

\section{Introduction}

The rise of mobile devices has created a new dynamic between consumers and brands, imposing new communication patterns, interactions, and relationships (Cambra-Fierro, Centeno, Olavarria, \& Vazquez-Carrasco, 2017). This interactional context promoted by technology has created the sharing economy, a global phenomenon that comprises commercial relationships based on the exchange of products and services between product owners/service providers and users, a connection

\footnotetext{
${ }^{1}$ Contact of the author Email: lucas.adm.unb@gmail.com
}

enabled by smartphone apps (Kumar, Lahiri, \& Dogan, 2018).

The app represents a virtual brand that provides the infrastructure of search, communication, payment, and evaluation, enabling users to find what they need and service providers to offer solutions (Ganapati \& Reddick, 2018), meaning an intrinsic relationship between users and virtual brands. In this sense, virtual brands must be appealing and inspiring so consumers can identify in them brand value, which will lead to consumers' preference and improved relationship with the brand (Lima, Irigaray, \& Lourenco, 2019). Building online relationships with 
consumers is a global strategy, a path to internationalize the brand and expand brand awareness through technology (Arnone, Colot, Croquet, Geerts, \& Pozniak, 2010; Guercini, Ranfagni, \& Runfola, 2020). However, despite the growth of the sharing economy, little is known about the relationship between users and virtual brands in the sharing economy context.

This discussion has led us to study the relation between users and virtual brands in the sharing economy using Customer Relationship Management (CRM). This managerial philosophy guides the relationship between customers and organizations by combining techniques from information technology and relationship marketing strategies to establish and maintain long-term and lucrative relationships between consumers and companies, creating relational benefits for both (Payne, 2012). For the author, CRM encompasses the interactions between technology, people, and processes. It fosters consumer loyalty. It is a valuable framework to investigate the sharing economy in which apps manage consumer information. One question arises from this context: what leads consumers to be loyal to virtual brands?

Although virtual brands in the context of sharing economy find in CRM theoretical background an adequate research path, the investigation of its drivers requires a dialogue between CRM and other constructs. Research signalizes the need to explore the role of the attribute of the brands in this context (Kumar et al., 2018; Lutz \& Newlands, 2018). In this scenario, a brand personality emerges as a first step into the development of long-term relationships between brands and consumers (Brito, 2010; Fournier, 1998) and an essential driver of loyalty, a central construct of CRM (Demo, Silva, Watanabe, \& Scussel, 2018). The concept of brand personality encompasses consumer perception of brands the same way they characterize a person (Aaker, 1997). We explore brand personality because of its positive effects on the associations customers create about brands when seeing brands as owners of personality traits, creating an affective relationship with such brands.

Therefore, the main objective of this study is to investigate the relation between brand personality and users' loyalty to virtual brands. We address this purpose by developing an investigation in the ridesharing scenario, the most emblematic modality of the sharing economy, about individual trips on demand through a digital online platform (Zha, Yin, \& Yang, 2016).

The virtual brands operating in this disruptive modality provide a high level of convenience, ease of payment, and affordable costs (Zha et al., 2016), demonstrating a strong focus on customers' needs (Rayna \& Striukova, 2016). This context converges with the theoretical framework of CRM, proving to be an adequate research locus to an investigation about loyalty in the digital context.

\section{Theoretical Framework}

\subsection{Customer relationship management}

Marketing literature understands Customer Relationship Management (CRM) as a holistic organizational philosophy focused on the attraction, maintenance, and development of relationships with customers through the interaction between the premises of relationship marketing and the capacity of information technology to create value for companies (Payne, 2012).

Relationship marketing is the conceptual foundation of CRM, an approach dedicated to the interaction between the company, its employees, departments and partners, and customers to create relational benefits for all the involved actors (Scussel, Petroll, Semprebon, \& Rocha, 2017). As stated by these authors, trust, satisfaction, and loyalty are the building blocks of relationship marketing, being fundamental concepts in CRM. In its turn, information technology emerges in CRM as a set of technological tools that allow companies to manage the relationships with customers, leveraging customer value by using relational strategies (Gupta \& Aggarwal, 2016).

By using knowledge as the main element of its strategies (Lau, Nakandala, Samaranayake, \& Shum, 2016), CRM enables firms to strategize in a global consumers' database, transcending national boundaries and creating global brands that can compete internationally (Khojastehpour \& Johns, 2014). In this sense, a brand can operate in different social and cultural contexts, addressing the relational strategy to the scenario in which consumers are located, but keeping the brand essence (Khojastehpour \& Johns 2014). These possibilities are connected to the context of virtual brands, 
considering the ubiquity brought by technology and the need of brands to be competitive.

However, Łukowski (2017) indicates that CRM in virtual relationships with consumers must be carefully analyzed. The evolution of information technology has led companies to create new ways of firm-customer interaction. In this scenario, companies resort to mobile marketing to map customers' journey and to interact with them at every touchpoint in an attempt to add value to their products and services, narrowing their relationship and differentiating from the competition (Malthouse, Haenlein, Skiera, Wege, \& Zhang, 2013).

This reality has promoted changes in the firmcustomer relationship, particularly concerning the more active role customers play in such relationships. They use the digital environment to filter ads, compare products and services, access reviews, interact with their favorite brands online, and share experiences and perceptions (Moreno \& Scussel, 2019). The business model's sustainability in the sharing economy platforms is related to developing mechanisms for retaining a broad user base (Akhmedova, Marimon, \& Mas-Machuca, 2020). To generate this base, sharing economy brands use customers' transaction history and evaluations of the experiences saved in real-time on their platforms, creating a valuable database for CRM improvement (Santoso \& Erdaka, 2015).

As a practical result of the adoption of CRM, the sharing economy platforms identify customers and their most profitable service providers. The classification of customers is usually carried out using the customer lifetime value or customer engagement value metrics; and service providers through a performance metric that encompasses service quality and aspects inherent to the idiosyncrasies of each activity (Kumar et al., 2018). The processing of customer and service provider evaluations results in consumer convenience regarding the availability of support on digital platforms and improved service provision procedures, aiming to generate consistent consumer experiences and enable secure transactions (Bugshan \& Attar, 2020).

The interaction between several factors regarding people, processes, and technologies to implement CRM, has become a complex task in managerial practice, demanding managers to adapt their plans and strategies to the idiosyncrasies of the organization, the market segment, consumer behavior, and market trends (Galvão, de Carvalho, Oliveira, \& Medeiros, 2018). Based on the particularities of the relationship between customers and brands in the digital environment (Moreno \& Scussel, 2019), it is plausible to say that the relational aspects of such interaction must be explored.

Nevertheless, we did not identify studies addressing CRM strategies in the context of virtual brands, especially concerning the factors considered by users that lead to a long-term relationship with virtual brands. The idea of a long-term relationship has led us to the concept of loyalty, a building block of relationship marketing (Delmondez, Demo, \& Scussel, 2017) and the main objective of CRM strategies (Payne, 2012). The most traditional loyalty in marketing literature indicates loyalty as a deep commitment of consumers in repeatedly buying or recommending a product or service (Oliver, 1999).

Literature also recognizes that the understanding of loyalty, its drivers, and consequences is contextdependent. In other words, loyalty must be studied in the context in which it is operationalized (Wolter, Bock, Smith, \& Cronin, 2017). Although loyalty has been a topic of great interest by marketing scholars, this content must be updated to the scenario in which brands and users relate digitally, addressing how loyalty is built in the digital context. Loyalty can not be measured the same way, as it comprises the time and space of the investigation and the social and economic conditions (Ngobo, 2017). For this reason, we focus on the relationship between users and virtual brands in an attempt to shed light on the antecedents of loyalty in a sharing economy virtual brand.

Following this objective, we decided to apply the CRM Scale proposed by Demo, Watanabe, Chauvet, and Rozzett (2017), a scientifically validated research instrument with reliable psychometric indexes composed of two factors: loyalty and customer service. In the present study, we used only the items from the Loyalty factor, as the other things do not apply to the context of virtual brands.

\subsection{Brand personality}

Brand personality is the set of human attributes associated with a brand, a construct reflecting consumers' perceptions about a brand the same way they would do with other individuals (Aaker, 1997). Brand personality is an outcome of a dynamic process 
of communication between a brand and its consumers, covering tangible attributes such as price and product design, and intangible factors like brand positioning, brand image and the way the brand interacts with customers (Liu, Huang, Hallak, \& Liang, 2016; Su \& Tong, 2015).

In this regard, we have found a connection between brand personality and relationship marketing. Since brand personality increases the symbolic value of commercial brands, it is recognized as a prerequisite for developing relationships between brands and consumers (Becheur, Bayarassou, \& Ghrib, 2017; Roy, Khandeparkar, \& Motiani, 2016). When consumers perceive personality traits in the brands and make a positive association, they tend to relate with the brand the same way they would establish and nurture a relationship with an individual carrying the same personality traits (Brito, 2010).

The stream of research dedicated to a brand personality in the consumer behavior and marketing arena encompasses e-brand personality regarding virtual brands. In other words, brands that offer products and services in the digital environment, the context in which communication is mediated by internet devices (Park, Choi, \& Kim, 2005), in line with our investigation about ridesharing. According to these scholars, consumers perceive e-brand personality based on the design of the online environment. The way brands communicate products and services and the interaction patterns with the audience. Hence, e-brand personality helps brands create a distinguished identity in the market, increasing online competitiveness.

E-brand personality is a crucial element for virtual brands to succeed in online relationship building (Ong, Nguyen, \& Syed Alwi, 2017). Similarly, Demo et al. (2018) confirmed that brand personality plays an essential role in the way users relate to social media platforms, keeping long-term relationships with social media that show to be reliable, innovative, and friendly. However, the literature lacks an understanding of the role of brand personality on virtual brands.

The literature considers the scale developed by Aaker (1997) as a milestone in brand personality studies. It is a reliable scientific research instrument capable of measuring brand personality through its five dimensions: Sincerity, Excitement, Competence, Sophistication, and Ruggedness. This scale was validated initially in the United States, but its internal consistency was confirmed by the subsequent studies that validated the instrument in other cultures: Spain and Japan (Aaker, Benet-Martínez, \& Garolera, 2001), Germany (Bosnjak, Bochmann, \& Hufschmidt, 2007), India (Ahmad \& Thyagaraj, 2017), Poland (Glińska \& Kilon, 2014), Jamaica (Baloglu, Henthorne, \& Sahin, 2014), Belgium (Geuens, Weijters, \& De Wulf, 2009) and Brazil (Muniz \& Marchetti, 2012).

As proposed in the systematic review performed by Scussel and Demo (2016), the scale validated by Muniz and Marchetti (2012) has set a new path for the development of studies about this construct in the Brazilian context, since brand personality is a variable that must respect the cultural scenario in which it is explored. The scale has been proved to be a helpful instrument, enabling studies about the personality of brands in the food and beverage sector (Delmondez et al., 2017; Moreno, Demo, \& Watanabe, 2020), social media (Demo et al., 2018) and luxury brands (Scussel \& Demo, 2019). Considering the reliable psychometric indices from Muniz and Marchetti's (2012) scale, this will be the research instrument used in the present study to measure brand personality.

\section{Method}

This paper reports an online survey with Brazilian users of ridesharing apps, investigating the impact of the personality of virtual brands on customer relationship perception.

To measure brand personality, we used the Brand Personality Scale validated in the Brazilian context by Muniz and Marchetti (2012), with 28 items distributed in five factors representing Credibility, Joy, Audacity, Sophistication, and Sensitivity. Regarding customer relationship perception, we used the Customer Relationship Scale validated by Demo et al. (2017), composed of two factors, loyalty and customer service. In this study, we used only the loyalty elements items (14 items) since the factor of customer service does not apply to the context of virtual brands.

To test the prediction relation between the variables, we performed linear regression through path analysis, via structural equation modeling, following Hair et al. (2014). To use this method, Cohen (1992) recommends a minimum sample with statistical power superior to 0.8. According to the 
software GPower 3.1, considering the five dimensions of the predictor variable (brand personality), the standard significance criterion $(\alpha)$ of 0.05, and the average effect size, the minimum sample should be 92 respondents.

Kline (2011) suggests a sample between 100 and 200 subjects for simple models with few variables, which is the case of this study. Besides, our model has 21 observations and 21 parameters, in other words, zero degrees of freedom, creating a recursive model classified as just identified and, because of this, adequate for a test with structural equation modeling, using the Maximum Likelihood criterion, following Kline's (2011) guidance. Structural equation modeling is a technique that examines the structure of the interrelations in a series of equations, combining multiple linear regression with one or more dependent variables and factor analysis (Hair et al., 2014; Kline, 2011). In this study, brand personality is the independent variable (five factors), and the dependent variable is customer relationship perception (one factor).

After data collection, we started a data treatment stage, following the instructions of Tabachnick and Fidell (2013). In this step, we excluded 21 incomplete questionnaires. To identify outliers, we used the Mahalanobis method, but no outliers were identified. The final sample had 580 subjects, satisfying the statistical criteria mentioned above. Most of the participants were young, between 18 and 27 years old (47\%) and 28 and 37 years old (36\%), corroborating the profile of ridesharing apps' users observed in previous research (Young \& Farber, 2019). Most of the subjects were female (58\%), with master's degree (36\%) or college education (27\%), and used ridesharing apps for at least two years (36\%), monthly (37\%), or weekly (36\%).

Next, we analyzed tolerance values, all superior to 0.10 , and the values concerning the variance inflation factor (VIF), all inferior to 10.00. These confirmed that the data did not present multicollinearity or singularity problems in our sample (Myers, 1990). Finally, we verified the assumptions for multivariate analysis, according to Hair et al. (2014). We analyzed normal probability graphs and residual graphs to verify data normality, linearity, and homoscedasticity (Field, 2017). All assumptions have been confirmed. Since we used structural equation modeling, multivariate normality was also analyzed (Marôco, 2010) in the software AMOS without any problems.

\section{Findings}

Firstly, we identified the brand personality of the most cited ridesharing virtual brands in this study. We performed this analysis only for the brands Uber and 99 since they showed a relative frequency of $85 \%$ and $13 \%$, respectively, representing $98 \%$ of our sample. Afterward, we verified the means of the dimensions of brand personality regarding the brands Uber and 99. By analyzing each virtual brand individually, we identified the most predominant brand personality of each brand. Figure 1 illustrates the dimensions of brand personality associated with each virtual brand.

Figure 1 - Means of the dimensions of brand personality associated with ridesharing virtual brands

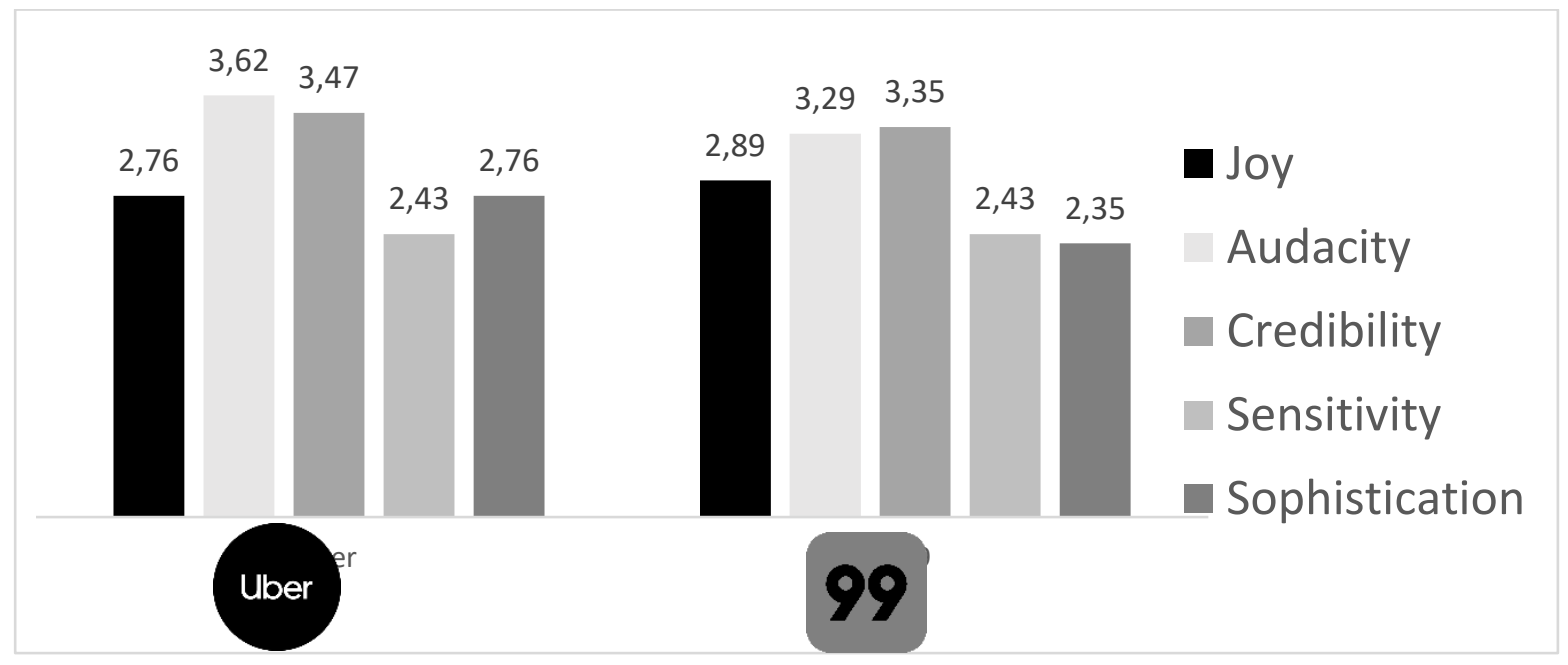


Figure 1 shows the global perception of the sample regarding ridesharing virtual brands' personalities. Results indicate Audacity and Credibility as the most prominent characteristics of virtual brands in the ridesharing sector, followed by Joy, Sophistication, and Sensitivity.

Users' perception about virtual brands' Audacity traits was not unexpected since this dimension of brand personality reflects brands known by the innovation capacity and their technological and creative products (Muniz \& Marchetti, 2012). Therefore, it is plausible to say that ridesharing consumers see these brands as modern and up-todate, valuing innovative products and services. This finding is in line with the results for consumers' perception about the innovativeness of social media brands, being audacity a critical driver of brand loyalty in the digital context (Demo et al., 2018).

Along with audacity, the credibility dimension is also paramount in ridesharing users' perception, as they see the virtual brands as reliable, consistent, and respectable. In the online scenario, credibility is the main factor for user preference and retention since this personality dimension sheds light on connection trustworthiness, privacy, and personal information safety (Demo et al., 2018).

The results for the Joy dimension represent a trade-off with the Credibility dimension. We understand if a brand is seen as reliable, secure, responsible, and respectable, it contrasts with Joy traits, which are playful, festive, and cool (Muniz \& Marchetti, 2012). The same interpretation happens with the Sophistication dimension, known for its traits of elegance, luxury, and difficult access to the brand (Muniz \& Marchetti, 2012; Scussel \& Demo, 2019), characteristics that do not match the availability, cost reduction, and easiness of the ridesharing sector (Zha et al., 2016). Lastly, the least perceived dimension was Sensitivity. Brands with Sensitivity traits tend to use emotional appeal in their communication strategies. In contrast, brands used by consumers day by day to make their lives easier use the rational appeal (Maehle, Otnes, \& Supphellen, 2011). It fits with the purposes of the sharing economy (Ganapati \& Reddick, 2018).

In the next step, considering the objective of analyzing the relation between brand personality and loyalty in the context of the sharing economy's virtual brands, we tested the measurement models of our research variables. Thus, the latent variables of the scales brand personality and customer relationship perception (the Loyalty factor) were submitted to Confirmatory Factor Analysis (CFA). The scales of brand personality (Muniz \& Marchetti, 2012) and customer relationship perception (Demo et al., 2017) were evaluated according to convergent and discriminant validity evidence.

Convergent validity reveals the degree of agreement between two or more measures of the same construct (Hair et al., 2014), which can be confirmed by the reliability of each factor (Nunnally \& Bernstein, 1994). In this study, the composed reliability of the brand personality factors was analyzed by Jöreskog's Rho, a more accurate measure of reliability compared to Cronbach's alpha in the case of structural equation modeling, since it is based on factor loads instead of correlations between the variables (Chin, 1998). According to this author, the Jöreskog's Rho indices are satisfactory when greater than 0.7. Additionally, we also checked the factor loads, considering values above 0.50 as desirable values (Hair et al., 2014).

Table 1 presents the results regarding convergent validity for the brand personality scale, demonstrating that all the standardized regression estimates reached values above 0.50 , as recommended by Hair et al. (2014). Moreover, all the dimensions achieved values over 0.70 for the Jöreskog's Rho. Therefore, we confirm convergent validity for all the dimensions of brand personality. 
Take a Ride on Credibility: The Role of Brand Personality in Users' Loyalty to Virtual Brands in the Sharing Economy

Table 1 - Confirmatory Factor Analysis for Brand Personality Scale

\begin{tabular}{|c|c|c|c|c|c|c|}
\hline & & Estimate & $\begin{array}{l}\text { Standard } \\
\text { Error }\end{array}$ & $\begin{array}{c}\text { Critical } \\
\text { Ratio }\end{array}$ & $\begin{array}{c}\text { Standardized } \\
\text { regression } \\
\text { estimate }\end{array}$ & $\begin{array}{l}\text { Rho de } \\
\text { Jöreskog }\end{array}$ \\
\hline \multirow{8}{*}{ Credibility } & Responsible & 1,00 & - & - & $0,76^{* *}$ & \multirow{8}{*}{0,90} \\
\hline & Secure & 0,98 & 0,06 & 17,36 & $0,71 * *$ & \\
\hline & Reliable & 0,99 & 0,05 & 19,47 & $0,78^{* *}$ & \\
\hline & Confident & 1,01 & 0,05 & 20,15 & $0,81^{* *}$ & \\
\hline & Corret & 0,92 & 0,06 & 15,22 & $0,63^{* *}$ & \\
\hline & Respectable & 0,97 & 0,05 & 18,67 & $0,76^{* *}$ & \\
\hline & Loyal & 1,02 & 0,05 & 20,10 & $0,80 * *$ & \\
\hline & Consistent & 0,77 & 0,06 & 12,25 & $0,52^{* *}$ & \\
\hline \multirow{7}{*}{ Joy } & Playful & 1,00 & - & - & $0,80 * *$ & \multirow{7}{*}{0,90} \\
\hline & Good-natured & 0,61 & 0,05 & 13,52 & $0,55^{* *}$ & \\
\hline & Fun & 0,96 & 0,04 & 21,75 & $0,80 * *$ & \\
\hline & Extrovert & 0,99 & 0,04 & 22,30 & $0,81^{* *}$ & \\
\hline & Festive & 0,85 & 0,05 & 18,78 & $0,72 * *$ & \\
\hline & Happy & 0,97 & 0,05 & 21,28 & $0,79 * *$ & \\
\hline & Cool & 0,99 & 0,04 & 22,86 & $0,83^{* *}$ & \\
\hline \multirow{5}{*}{ Sophistication } & Sophisticated & 1,00 & - & - & $0,80 * *$ & \multirow{5}{*}{0,88} \\
\hline & Upper class & 0,96 & 0,05 & 21,05 & $0,79 * *$ & \\
\hline & Elegant & 0,92 & 0,05 & 20,28 & $0,78^{* *}$ & \\
\hline & Chic & 0,90 & 0,05 & 18,81 & $0,73 * *$ & \\
\hline & Glamorous & 0,89 & 0,05 & 19,00 & $0,74 * *$ & \\
\hline \multirow{4}{*}{ Audacity } & Up-to-date & 1,00 & - & - & $0,75^{* *}$ & \multirow{4}{*}{0,81} \\
\hline & Creative & 0,86 & 0,05 & 16,73 & $0,75^{* *}$ & \\
\hline & Daring & 0,88 & 0,06 & 16,02 & $0,74^{* *}$ & \\
\hline & Modern & 0,87 & 0,06 & 15,00 & $0,64 * *$ & \\
\hline \multirow{4}{*}{ Sensibility } & Enchanting & 1,00 & - & - & $0,81^{* *}$ & \multirow{4}{*}{0,86} \\
\hline & Sensitive & 1,04 & 0,05 & 21,63 & $0,80 * *$ & \\
\hline & Delicate & 0,91 & 0,05 & 20,10 & $0,75^{* *}$ & \\
\hline & Romantic & 1,00 & 0,05 & 20,74 & $0,78^{* *}$ & \\
\hline
\end{tabular}

Nota. ${ }^{* *}$ p-value $<0.01$

Table 2 presents convergent validity analysis for the Customer Relationship Scale (the Loyalty factor). All the factor loads were above 0.50, as Hair et al. (2014) suggested, and significant considering $p$ value $<0.01$. In addition, the Jöreskog's Rho for this unifactorial solution was 0.94 . Hence, we confirm convergent validity. Lastly, we note that the average variance extracted (AVE) was 0.51, satisfying the literature recommendation. 
Table 2 - Confirmatory Factor Analysis for Customer Relationship Scale

\begin{tabular}{l|c|c|c|c}
\hline & Estimate & $\begin{array}{c}\text { Standard } \\
\text { Error }\end{array}$ & Critical Ratio & $\begin{array}{c}\text { Standardized } \\
\text { regression } \\
\text { estimate }\end{array}$ \\
\hline $\begin{array}{l}\text { My experiences with this brand exceed my } \\
\text { expectations }\end{array}$ & 1.00 & - & - & $0.78^{* *}$ \\
\hline This brand treats me with respect and attention & 1.09 & 0.06 & 17.65 & $0.78^{* *}$ \\
\hline I recommend this brand to my family and friends & 1.05 & 0.06 & 17.53 & $0.77^{* *}$ \\
\hline This brand keeps its promises & 1.04 & 0.06 & 17.30 & $0.68^{* *}$ \\
\hline This brand s fast in problem solution assistance & 1.07 & 0.07 & 15.45 & $0.80^{* *}$ \\
\hline I identify with this brand & 1.28 & 0.07 & 17.84 & $0.68^{* *}$ \\
\hline $\begin{array}{l}\text { I am willing to use this brands' service and } \\
\text { product again }\end{array}$ & 1.05 & 0.07 & 15.32 & $0.69^{* *}$ \\
\hline I feel an important customer to this brand & 1.20 & 0.08 & 15.12 & $0.74^{* *}$ \\
\hline $\begin{array}{l}\text { The advertising of this brand is in line with its } \\
\text { offers }\end{array}$ & 1.13 & 0.07 & 16.53 & $0.74^{* *}$ \\
\hline $\begin{array}{l}\text { The product and services of this brand have } \\
\text { quality }\end{array}$ & 1.06 & 0.06 & 16.51 & $0.83^{* *}$ \\
\hline \begin{tabular}{l} 
This brand deserves my trust \\
\hline This brand offers me personalized service
\end{tabular} & 1.22 & 0.07 & 18.45 & $0.59^{* *}$ \\
\hline $\begin{array}{l}\text { The prices of the products and services of this } \\
\text { brand are fair }\end{array}$ & 0.96 & 0.07 & 13.96 & $0.61^{* *}$ \\
\hline $\begin{array}{l}\text { This brand is the best option comparing to the } \\
\text { other brands in the market }\end{array}$ & 1.02 & 0.07 & 13.82 & $0.78^{* *}$ \\
\hline
\end{tabular}

Note. ${ }^{* *}$ p-value $<0.01$

Discriminant validity reports the degree to which a construct differs from other constructs (Hair et al., 2014). To attest discriminant validity, the researcher must compare, for each dimension, the square root of the average variance extracted (AVE) with the correlations between them. The researcher has to observe evidence of discriminant validity when the value of the AVE's square root for each dimension is greater than the correlation square between them, according to the Fornell-Larcker criterion (Hair et al., 2014). Since the brand personality scale is multidimensional, we tested discriminant validity for its factors. Table 3 illustrates the results. The Customer Relationship Scale has only one element (Loyalty), being unnecessary to be tested for discriminant validity.

Table 3 - Discriminant Validity for Brand Personality Scale

\begin{tabular}{lccccc}
\hline & Credibility & Joy & Sophistication & Audacity & Sensitivity \\
\cline { 2 - 6 } Credibility & $0.73 \underline{a}$ & & & & \\
Joy & 0.30 & $0.76 \underline{a}$ & & & \\
Sophistication & 0.42 & 0.54 & $0.77 \underline{a}$ & & \\
Audacity & 0.63 & 0.36 & 0.43 & $0.72 \underline{a}$ & \\
Sensitivity & 0.30 & 0.85 & 0.68 & 0.30 & $0.78 \underline{a}$ \\
\hline AVE & 0.53 & 0.58 & 0.59 & 0.52 & 0.62 \\
\hline
\end{tabular}

Note. a Square root of the average variance extracted (AVE).

In the following, we performed the analysis of model fit indices. Hair et al. (2014) stated three categories of fit indices recommended to evaluate measurement models and structural models: absolute, incremental, and parsimony indices. The absolute fit indices express the degree to which the 
proposed model (structural and measurement models together) fits the empirical model (observed data). According to the authors, the incremental fit indices compare the proposed model with a simpler alternative model, the null model. It measures only one construct and its observable variables without a measurement error. Finally, the parsimony fit indices compare the general fit of the model to the number of estimated coefficients necessary to reach the level of fit obtained.

To evaluate the measurement model, Kline (2011) recommends one incremental and one absolute index, in addition to the chi-square value and the associated degrees of freedom. We analyzed the following indices: (i) CMIN/DF, where CMIN is the $\chi^{2}$ statistic, and DF means the degrees of freedom of the model; (ii) the Comparative Fit Index - CFI; and (iii) the Root Mean Square Error of Approximation RMSEA, addressing the recommendations from Hair et al. (2014). Regarding the acceptable values, Hair et al. (2014), Kline (2013), and Byrne (2016) agree that CMIN/DF must up to 3.0 or at most 5.0; CFI equals or above 0.90, and RMSEA must achieve values under 0.08 .

Table 4 presents the results concerning the brand personality scale. All variables proved to be significant ( $p$-value <0.01). We understand the multifactorial structure has a good fit since all the parameters are within literature recommendations. Therefore, the internal validity of the brand personality scale is verified. In addition, the five-factor structure with 28 items, validated by Muniz and Marchetti (2012), remained stable, reinforcing the evidence of external validity.

Table 4 - Fit indices of the confirmatory analysis for the brand personality scale

\begin{tabular}{ccc}
\hline Parameters & Reference & Result \\
\hline CMIN/DF & $<5.00$ & 4.06 \\
CFI & $\geq 0.90$ & 0.90 \\
RMSEA & $<0.10$ & 0.07 \\
\hline
\end{tabular}

Table 5 shows the results for the Loyalty factor from the Customer Relationship Scale (Demo et al.,
2017), indicating a satisfactory model fit. Hence, we confirm the internal and external validity of the scale.

Table 5 - Fit indices of the confirmatory analysis for the customer relationship scale

\begin{tabular}{ccc}
\hline Parameters & Reference & Result \\
\hline CMIN/DF & $<5.00$ & 4.74 \\
CFI & $\geq 0.90$ & 0.93 \\
RMSEA & $<0.10$ & 0.09 \\
\hline
\end{tabular}

After the confirmation of the measurement model, we performed path analysis to test the relation between brand personality and loyalty in the context of the sharing economy's virtual brands. The structural model test also confirms the nomological validity of both scales since we tested the prediction power of brand personality on loyalty, previous corroborating research (Delmondez et al., 2017; Demo et al., 2018; Scussel \& Demo, 2019).

To test the structural model fit of the relation between brand personality and loyalty, we considered loyalty as the endogenous variable and, as exogenous variables, the five dimensions of brand personality (Credibility, Joy, Audacity, Sophistication, and Sensitivity). First, we analyzed the correlation between variables. Results indicate significant and positive correlations ranging from moderate $(>0.3)$ to strong (>0.5), as proposed by Cohen (1992), allowing the analysis of the prediction between variables (Field, 2017). Figure 2 illustrates the structural model and the obtained fit indices. 
Figure 2-Structural Model

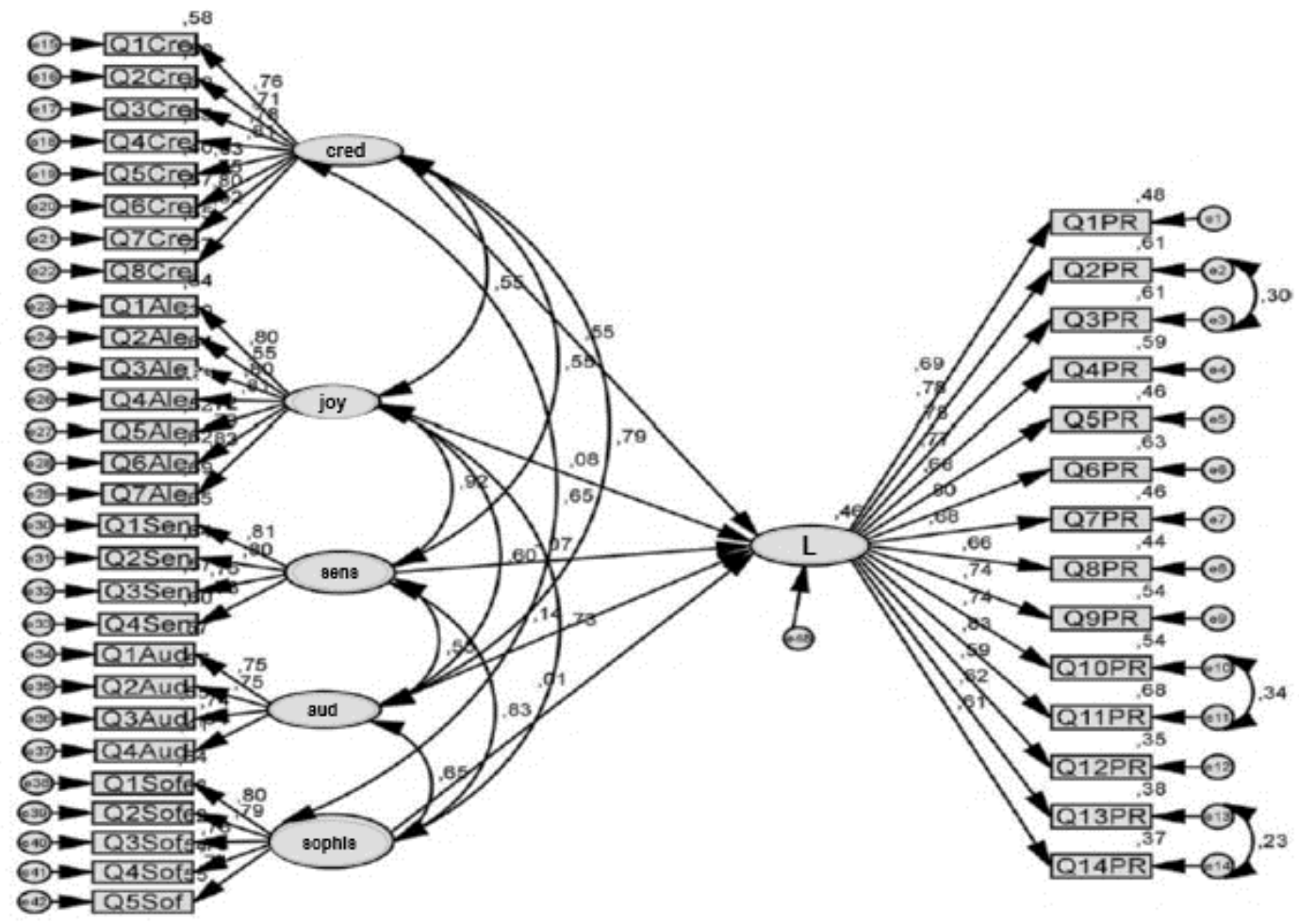

Note. $\mathrm{CMIN} / \mathrm{DF}=3.05, \mathrm{p}<0.001 ; \mathrm{CFI}=0.90 ; \mathrm{RMSEA}=0.06$

All the fit indices were adequate, confirming the proposed structural model and the influence of the brand personality of ridesharing virtual brands on users' loyalty. Table 6 shows the path analysis results. The standardized regression estimate represents the magnitude and the direction of the relationship between the endogenous variable (loyalty) and the exogenous variables (brand personality dimensions), revealing that only the credibility dimension had a significant statistical impact on loyalty.

Table 6 - Path Analysis

\begin{tabular}{ccccccc}
\hline & & Estimate & $\begin{array}{c}\text { Standard } \\
\text { Error }\end{array}$ & $\begin{array}{c}\text { Critical } \\
\text { Ratio }\end{array}$ & $\begin{array}{c}\text { Standardized } \\
\text { regression } \\
\text { estimate }\end{array}$ \\
\hline Credibility & $\rightarrow$ & CRP & 0.44 & 0.06 & 6.95 & $0.55^{* *}$ \\
Joy & $\rightarrow$ & CRP & 0.05 & 0.11 & 0.49 & 0.08 \\
Audacity & $\rightarrow$ & CRP & 0.10 & 0.06 & 1.55 & 0.137 \\
Sensibility & $\rightarrow$ & CRP & -0.05 & 0.15 & -0.35 & -0.07 \\
Sophistication & $\rightarrow$ & CRP & 0.01 & 0.07 & 0.13 & 0.01 \\
\hline
\end{tabular}

Note. ${ }^{* *}$ p-value $<0.01$

By analyzing the standardized regression coefficient $(\beta)$, we observe a positive relationship between credibility and loyalty. This dimension of brand personality is the only predictor of customer relationship perception confirmed in this research model. Cohen (1992) categorizes the statistical impact of the regression determination coefficient
$\left(R^{2}\right)$ as small (0.02), medium (0.13), and large (0.26). Figure 2 showed that the dependent variable (customer relationship perception) variance is explained in $46 \%$ by the independent variables. Thus, through the credibility dimension, we conclude that brand personality significantly affects customer relationship perception in the ridesharing sector. 


\subsection{Discussion}

The main objective of this article was to investigate the relation between brand personality and users' loyalty to virtual brands. Results show that ridesharing users evaluate virtual brands that offer this specific kind of service in terms of personality traits and tend to relate to such brands. From this, we confirm that users recognize brands' efforts to create personalized apps and, consequently, service provision consistent with users' demands. Moreover, the relationship tends to be enhanced when virtual brands are perceived as reliable. In other words, when users see credibility traits in a virtual brand, they tend to be more loyal to the virtual brand. Users interpret their experiences with virtual brands as reflecting a responsible, confident, trustworthy, correct, respectful, loyal, and consistent brand. Thus, our findings validate the proposed theoretical model, confirming the influence of brand personality on customer loyalty.

The results show that credibility is the primary driver of users' loyalty. Hence, when customers identify a brand as reliable, consistent, and trustworthy, they will prefer this brand and bond with it. In fact, as Sweeney and Swait (2008) indicate, credibility - or the lack of it - directly affects brands' image and reputation, being an essential aspect to be considered by brand managers in their strategy formulation processes. The ridesharing sector has a good fit with this perspective since users of virtual brands are more susceptible to use platforms known for their safety and reliability. We observed that the ridesharing brands (Uber and 99) show in their websites and apps a field that exposes their safety concerns. Regarding user safety, these brands highlight the trip record using GPS, the availability of a trained team to deal with complaints and any kind of accusation about the drivers, the tools for trip sharing with users' contacts, and the option to call the police in an emergency. The brands also check the criminal background of candidates for drivers as one of the steps in their application.

Since credibility refers to the trust consumers have in a brand's intentions (Muniz \& Marchetti, 2012) and trust is a building block of relationship marketing (Scussel \& Demo, 2017), we conclude that users believe ridesharing virtual brands' capacity of keeping their promises. This belief fosters their loyalty to these brands.

\subsection{Implications, limitations \& further studies}

The main contribution of this research for relationship marketing and consumer behavior lies in understanding the brand personality as an antecedent of loyalty and, more importantly, a driver of CRM. The perception of brand personality traits in virtual brands will lead users to relate with such brands and build long-term relationships based on loyalty and the relational benefits it brings for both parties. Besides filling a literature gap (Delmondez et al., 2017; Scussel \& Demo, 2016), we explore the relational aspects of the digital environment, a theme underexplored in literature, although a growing market segment that demands scientific investigations (Moreno \& Scussel, 2019). We contribute to the product and service innovation literature as our findings show what users find relevant in their preferences. These can be used in app design, big data management, virtual brand creation, and other technological devices that connect users and service providers.

As managerial implications, our findings can be used by marketing practitioners in their communication, branding, and relationship strategies' development in a more effective way, considering the credibility dimension attributes and the impact such characteristics have on consumers' intention to relate with virtual brands. Considering CRM as an efficient strategy to focus on customers' needs, ridesharing brands' managers must emphasize in their actions the association between credibility traits, level of service quality, and user safety, creating branding and communication strategies that highlight such attributes. We foresee an opportunity to generate an emotional connection with users since they value virtual brands perceived as reliable. Another practical contribution of ours lies in presenting a competitive overview of ridesharing virtual brands. This information can be used for benchmarking to inspire managers in this sector to develop competitive intelligence.

As for limitations, we indicate the cross-sectional nature of our data, turning the results more indicative than conclusive, exposing the need for further investigation on this matter. The fact that data were collected exclusively online is another limitation since the dissemination of the electronic questionnaire was carried out through social networks and e-mail, restricting the sample to groups with similar social and demographic characteristics, generating a 
particular sample bias. Nevertheless, studies show that the average profile of ridesharing users is similar to the sample surveyed (Young \& Farber, 2019).

For future research, we advise scholars to explore other profile groups to understand their relationship with virtual brands, particularly considering the technology level of acceptance as a possible moderator of such relation. We recommend replicating this study in different cultural and social contexts to compare differences in the relationship between virtual brands and users from various nationalities. We suggest other research methods such as participant observation, interviews, netnography, and online communities of virtual brands analysis to develop a deeper understanding of user behavior. Additionally, we recommend the validation of both instruments, customer relationship perception, and brand personality, to the context of virtual brands, encompassing this segment's particularities and users. Lastly, we propose replicating our theoretical model to other sharing economy sectors, expanding the knowledge about this growing industry.

\section{Conclusion}

The present study represents a seminal step in investigating the relational aspects of the interaction between consumers and virtual brands in the sharing economy. It has brought the need to rethink brand management and brand positioning in the context of virtual brands and the imperative of redesign business strategies in the relationship marketing perspective.

\section{References}

Aaker, J. (1997). Dimensions of Brand Personality. Journal of Marketing Research, 34(3), 347-356.

Aaker, J., Benet-Martínez, V., \& Garolera, J. (2001). Consumption symbols as carriers of culture: A study of Japanese and Spanish brand personality constucts. Journal of Personality and Social Psychology, 81(3), 492-508.

Ahmad, A., \& Thyagaraj, K. S. (2017). An empirical comparison of two brand personality scales: Evidence from India. Journal of Retailing and Consumer Services, 36(January), 86-92.
Akhmedova, A., Marimon, F., \& Mas-Machuca, M. (2020). Winning strategies for customer loyalty in the sharing economy: A mixed-methods study. Journal of Business Research, 112, 33-44.

Arnone, L., Colot, O., Croquet, M., Geerts, A., \& Pozniak, L. (2010). Company Managed Virtual Communities in Global Brand Strategy. Global Journal of Business Research, 4(2), 97-102.

Baloglu, S., Henthorne, T. L., \& Sahin, S. (2014). Destination Image and Brand Personality of Jamaica: A Model of Tourist Behavior. Journal of Travel and Tourism Marketing, 31(8), 1057-1070.

Becheur, I., Bayarassou, O., \& Ghrib, H. (2017). Beyond Brand Personality: Building Consumer-Brand Emotional Relationship. Global Business Review, 18(3_suppl), S128-S144.

Bosnjak, M., Bochmann, V., \& Hufschmidt, T. (2007). Dimensions of Brand Personality Attributions: a Person-Centric Aproach in the German Cultural Context. Social Behavior and Personality: An International Journal, 35(3), 303-316.

Brito, C. (2010). Uma abordagem relacional ao valor da marca. Revista Portuguesa e Brasileira de Gestão, 9(1-2), 49-63.

Bugshan, H., \& Attar, R. W. (2020). Social commerce information sharing and their impact on consumers. Technological Forecasting and Social Change, 153, 119875.

Cambra-Fierro, J. J., Centeno, E., Olavarria, A., \& Vazquez-Carrasco, R. (2017). Success factors in a CRM strategy: technology is not all. Journal of Strategic Marketing, 25(4), 316-333.

Chin, W. (1998). The partial least squares approach to structural equation modeling. In G. Marcoulides (Ed.), Modern methods for business research (pp. 295-336). New York: Taylor \& Francis.

Cohen, J. (1992). A Power Primer. Psychological Bulletin, 112(1), 155-159.

Delmondez, F., Demo, G., \& Scussel, F. B. C. (2017). Você é o que Você Vende: A Influência da Personalidade de Marca no Relacionamento com Clientes de Empresas de Fast-Food. Revista Brasileira de Marketing, 16(04), 563-578. 
Take a Ride on Credibility: The Role of Brand Personality in Users' Loyalty to Virtual Brands in the Sharing Economy

Demo, G., Silva, T. L. da, Watanabe, E., \& Scussel, F. B. C. (2018). Credibility, audacity and joy: Brand personalities that connect users to social media. $B A R$ - Brazilian Administration Review, 15(4).

Demo, G., Watanabe, E., Chauvet, D., \& Rozzett, K. (2017). Customer Relationshio Management Scale for th2 B2C Market: A Cross-cultural Comparison. RAM. Revista de Administração Mackenzie, 18(3), 42-69.

Field, A. (2017). Discovering Statistics Using IBM SPSS (Fifth). Sage Publications.

Fournier, S. (1998). Consumers and Their Brands: Developing Relationship Theory in Consumer Research. Journal of Consumer Research, 24(4), 343353.

Galvão, M. B., de Carvalho, R. C., Oliveira, L. A. B. de, \& Medeiros, D. D. de. (2018). Customer loyalty approach based on CRM for SMEs. Journal of Business \& Industrial Marketing, 33(5), 706-716.

Ganapati, S., \& Reddick, C. G. (2018). Prospects and challenges of sharing economy for the public sector. Government Information Quarterly, 35(1), 7787.

Geuens, M., Weijters, B., \& De Wulf, K. (2009). A new measure of brand personality. International Journal of Research in Marketing, 26(2), 97-107.

Glińska, E., \& Kilon, J. (2014). Desirable Traits of the City Brand Personality in the Opinion of Managers for the Promotion of the City Government in Poland1. Procedia-Social and Behavioral Sciences, 156(April), 418-423.

Guercini, S., Ranfagni, S., \& Runfola, A. (2020). Ecommerce internationalization for top luxury fashion brands: some emerging strategic issues. Journal of Management Development, 39(4), 423-436.

Gupta, G., \& Aggarwal, H. (2016). Analysing customer responses to migrate strategies in making retailing and CRM effective. International Journal of Indian Culture and Business Management, 12(1), 92127.

Hair, J. F., Black, W. C., Babin, B. J., Anderson, R. E., \& Tatham, R. L. (2014). Análise Multivariada de Dados. Bookman Editora.
Khojastehpour, M., \& Johns, R. (2014). Internationalization and relationship marketing: an introduction. European Business Review, 26(3), 238253.

Kline, R. (2011). Convergence of Structural Equation Modeling and Multilevel Modeling. In The SAGE Handbook of Innovation in Social Research Methods (pp. 562-589).

Kumar, V., Lahiri, A., \& Dogan, O. B. (2018). A strategic framework for a profitable business model in the sharing economy. Industrial Marketing Management, 69(April), 147-160.

Lau, H., Nakandala, D., Samaranayake, P., \& Shum, P. K. (2016). BPM for supporting customer relationship and profit decision. Business Process Management Journal, 22(1), 231-255.

Lima, V. M., Irigaray, H. A. R., \& Lourenco, C. (2019). Consumer engagement on social media: insights from a virtual brand community. Qualitative Market Research: An International Journal, 22(1), 1432.

Liu, Z., Huang, S., Hallak, R., \& Liang, M. (2016). Chinese consumers' brand personality perceptions of tourism real estate firms. Tourism Management, 52, 310-326.

Łukowski, W. (2017). The role of knowledge management in mobile marketing. Marketing Instytucji Naukowych i Badawczych, 3(25), 135-155.

Lutz, C., \& Newlands, G. (2018). Consumer segmentation within the sharing economy: The case of Airbnb. Journal of Business Research, 88(December 2017), 187-196.

Maehle, N., Otnes, C., \& Supphellen, M. (2011). Consumers' perceptions of the dimensions of brand personality. Journal of Consumer Behaviour, 10(5), 290-303.

Malthouse, E. C., Haenlein, M., Skiera, B., Wege, E., \& Zhang, M. (2013). Managing customer relationships in the social media era: Introducing the social CRM house. Journal of Interactive Marketing, 27(4), 270-280. 
Marôco, J. (2010). Análise de equações estruturais: Fundamentos teóricos, software \& aplicações. Pêro Pinheiro: ReportNumber.

Moreno, L., Demo, G., \& Watanabe, E. (2020). O Doce Sabor da Influência da Personalidade de Marca no Relacionamento com Clientes no Mercado de Chocolates. Revista Brasileira de Marketing, 19(1), 01-28.

Moreno, L., \& Scussel, F. B. C. (2019). Customer Relationship Management: Finding New Tracks for the Field from a Systematic Review. XXII Seminário de Administração (SemeAD). São Paulo: XXII Seminário de Administração (SemeAD).

Muniz, K. M., \& Marchetti, R. Z. (2012). Brand personality dimensions in the Brazilian context. BAR Brazilian Administration Review, 9(2), 168-188.

Myers, R. H. (1990). Classical and Modern Regression with Applications (2nd ed.). Belmont, CA: Duxbury press.

Ngobo, P. V. (2017). The trajectory of customer loyalty: an empirical test of Dick and Basu's loyalty framework. Journal of the Academy of Marketing Science, 45(2), 229-250.

Nunnally, J., \& Bernstein, I. (1994). The Theory of Measurement Error. In Psychometric Theory (3rd ed., pp. 209-247). New York: McGraw-Hill Series in Psychology.

Oliver, R. L. (1999). Whence Consumer Loyalty? Journal of Marketing, 63, 33.

Ong, K. S., Nguyen, B., \& Syed Alwi, S. F. (2017). Consumer-based virtual brand personality (CBVBP), customer satisfaction and brand loyalty in the online banking industry. International Journal of Bank Marketing, 35(3), 370-390.

Park, S., Choi, D., \& Kim, J. (2005). Visualizing EBrand Personality: Exploratory Studies on Visual Attributes and E-Brand Personalities in Korea. International Journal of Human-Computer Interaction, 19(1), 7-34.

Payne, A. (2012). Handbook of CRM: Achieving Excellence in Customer Management. Elsevier Inc.
Rayna, T., \& Striukova, L. (2016). 360 business model innovation: Toward an integrated view of business model innovation. Research Technology Management, 59(3), 21-28.

Roy, P., Khandeparkar, K., \& Motiani, M. (2016). A lovable personality: The effect of brand personality on brand love. Journal of Brand Management, 23(5), 97-113.

Santoso, A. S., \& Erdaka, A. (2015). Customer Loyalty in Collaborative Consumption Model: Empirical Study of CRM for Product-Service SystemBased e-Commerce in Indonesia. Procedia Computer Science, 72, 543-551.

Scussel, F. B. C., \& Demo, G. (2016). Personalidade de Marca: Itinerários da Produção Nacional e Agenda de Pesquisa. Revista Brasileira de Marketing, 15(03), 340-354.

Scussel, F. B. C., \& Demo, G. (2017). Diga-Me O Que Vestes E Te Direi Quem És: Um Estudo Sobre a Personalidade Das Marcas De Moda De Luxo. Revista Eletrônica de Estratégia \& Negócios, 10(1), 77.

Scussel, F. B. C., \& Demo, G. (2019). The relational aspects of luxury consumption in Brazil: the development of a Luxury Customer Relationship Perception Scale and the analysis of brand personality influence on relationship perception on luxury fashion brands. Brazilian Business Review, 16(2), 174190.

Scussel, F. B. C., Petroll, M. M., Semprebon, E., \& Rocha, R. A. (2017). O Que É, Afinal, Marketing de Relacionamento? Uma Proposta de Conceito Unificador. Revista de Ciências Da Administração, 19(48), 9-23.

Su, J., \& Tong, X. (2015). Brand personality and brand equity: Evidence from the sportswear industry. Journal of Product and Brand Management, 24(2), 124-133.

Sweeney, J., \& Swait, J. (2008). The effects of brand credibility on customer loyalty. Journal of Retailing and Consumer Services, 15(3), 179-193.

Tabachnick, B., \& Fidell, L. S. (2013). Using Multivariate Statistics (6th Editio). Boston: Pearson. 
Wolter, J. S., Bock, D., Smith, J. S., \& Cronin, J. J. (2017). Creating Ultimate Customer Loyalty Through Loyalty Conviction and Customer-Company Identification. Journal of Retailing, 93(4), 458-476.

Young, M., \& Farber, S. (2019). The who, why, and when of Uber and other ride-hailing trips: An examination of a large sample household travel survey. Transportation Research Part A: Policy and Practice, 119, 383-392.

Zha, L., Yin, Y., \& Yang, H. (2016). Economic analysis of ride-sourcing markets. Transportation Research Part C: Emerging Technologies, 71, 249266.

\section{ABOUT THE AUTHORS:}

Lucas Moreno - Universidade de Brasília - UnB, Brasília, DF (Brasil). Email: lucas.adm.unb@gmail.com Orcid id: https://orcid.org/0000-0003-4764-2652

Gisela Demo - Universidade de Brasília - UnB, Brasília, DF (Brasil). Email: giselademo@unb.br https://orcid.org/0000-0003-1864-0471

Thelma Valéria Rocha - Escola Superior de Propaganda e Marketing - ESPM, São Paulo, SP (Brasil). Email: tvrocha@espm.br Orcid id: https://orcid.org/0000-0002-3825-4343

Fernanda Scussel - Universidade Federal de Santa Catarina - UFSC, Florianopolis, SC (Brasil). Email: contatofernandascussel@gmail.com Orcid id: https://orcid.org/0000-0001-7953-6710 


\title{
Pegue Carona na Credibilidade: O Papel da Personalidade de Marca na Lealdade dos Usuários a Marcas Virtuais na Economia Compartilhada
}

\author{
Lucas Moreno, Gisela Demo, Thelma Valéria Rocha ${ }^{\ddagger}$, Fernanda Scussel ${ }^{*}$ \\ Universidade de Brasília - UnB, Brasília, DF (Brasil) \\ Escola Superior de Propaganda e Marketing - ESPM, São Paulo, SP (Brasil) ${ }^{\ddagger}$ \\ Universidade Federal de Santa Catarina - UFSC, Florianopolis, SC (Brasil) ${ }^{\sharp}$
}

\begin{tabular}{l} 
DETALHES DO ARTIGO \\
\hline Histórico do Artigo: \\
Received: 01 Julho 2020 \\
Accepted: 15 Abril 2021 \\
Available online May: 01 th 2021 \\
Sistema de revisão “Double blind \\
review” \\
Editor Científico \\
Ilan Avrichir \\
\hline Palavras-chaves: \\
Gestão do Relacionamento com Clientes \\
Lealdade \\
Personalidade de Marca \\
Marcas Virtuais \\
Economia Compartilhada
\end{tabular}

Internext | São Paulo, v.16, n. 2, p. 221-237, mai./ago. 2021

\section{RESUMO}

Objetivo: Embora a economia compartilhada seja um fenômeno global, configurando um caminho para criar marcas internacionais com um alcance de clientes em todo o mundo, a relação entre as marcas virtuais e os usuários neste novo setor permanece pouco explorada, o que nos leva a investigar a relação entre a personalidade da marca e a lealdade dos usuários às marcas virtuais.

Método: Realizamos uma pesquisa com 580 usuários de aplicativos de carona, utilizando modelagem de equações estruturais para testar a relação de predição da personalidade de marca sobre a lealdade dos usuários.

Resultados: A presente pesquisa retrata os aspectos intangíveis da relação entre usuários e marcas no ambiente digital, revelando os traços de personalidade das marcas virtuais e o impacto na fidelização do cliente no contexto da economia compartilhada. Credibilidade e audácia são as características mais marcantes das marcas virtuais, sendo a credibilidade o principal fator de fidelização.

Contribuições: Esses achados contribuem para o corpo de conhecimento do marketing de relacionamento, na medida em que fornece informações sobre a forma como os clientes se relacionam com suas marcas virtuais favoritas e indica um antecedente do marketing de relacionamento. Os estudos do relacionamento consumidor-marca também se beneficiam de nossos resultados, uma vez que indicamos fatores importantes que permitem associações positivas sobre uma marca na mente dos consumidores.

Relevância/Originalidade: Este estudo representa uma etapa seminal na investigação dos aspectos relacionais da interação entre usuários e marcas virtuais na economia do compartilhamento, o que trouxe a necessidade de repensar a gestão e o posicionamento da marca no contexto das marcas virtuais. 


\title{
Dé un Paseo por la Credibilidad: El Papel de la Personalidad de la Marca en la Lealtad de los Usuarios a las Marcas Virtuales en la Economía Compartida
}

\author{
Lucas Moreno, Gisela Demo, Thelma Valéria Rocha ${ }^{\ddagger}$, Fernanda Scussel ${ }^{*}$ \\ Universidade de Brasília - UnB, Brasília, DF (Brasil) \\ Escola Superior de Propaganda e Marketing - ESPM, São Paulo, SP (Brasil) ${ }^{£}$ \\ Universidade Federal de Santa Catarina - UFSC, Florianopolis, SC (Brasil) ${ }^{*}$
}

HISTORIA DEL ARTÍCULO
Historia del Artículo:
Recibido: 01 de Julio de 2020
Aceptado: 15 de Abril de 2021
Disponible en línea: 01 de Mayo 2021
Double Blind Review System
Editor Científico
Ilan Avrichir

\section{Palabras-clave:}

Gestión de la relación con el cliente; Lealtad

Personalidad de marca

Marcas virtuales

Economía compartida

\section{RESUMEN}

Objetivo: Aunque la economía colaborativa es un fenómeno global, siendo un camino para crear marcas internacionales con un alcance de clientes en todo el mundo, la relación entre las marcas virtuales y los usuarios en este nuevo sector sigue siendo poco explorada, lo que nos lleva a investigar la relación entre la personalidad de la marca y la lealtad de los usuarios a las marcas virtuales.

Método: Realizamos una encuesta con 580 usuarios de aplicaciones de viajes, utilizando modelos de ecuaciones estructurales para probar la relación predictiva de la personalidad de la marca sobre la fidelización del usuario.

Resultados: La presente investigación describe los aspectos intangibles de la relación entre usuarios y marcas en el entorno digital, revelando los rasgos de personalidad de las marcas virtuales y el impacto en la lealtad del cliente en el contexto de la economía colaborativa. La credibilidad y la audacia son las características más destacadas de las marcas virtuales, siendo la credibilidad el principal motor de la fidelidad.

Contribuciones: Estos hallazgos contribuyen al cuerpo de conocimiento del marketing relacional, en el sentido de que brindan información sobre la forma en que los clientes se relacionan con sus marcas virtuales favoritas e indica un antecedente del marketing relacional.

Relevancia/Originalidad: Este estudio representa un paso fundamental en la investigación de los aspectos relacionales de la interacción entre usuarios y marcas virtuales en la economía colaborativa, lo que ha traído la necesidad de repensar la gestión de marca y el posicionamiento de marca en el contexto de las marcas virtuales.

\section{How to cite this article}

Moreno, L., Demo, G., Rocha, T., \& Scussel, F. (2021). Take a Ride on Credibility: the role of brand personality in users' loyalty to virtual brands in the Sharing Economy. Internext, 16(2), 221-237. doi: http://dx.doi.org/10.18568/internext.v16i2.670 